\title{
An Examination of Teachers' Views Regarding the Conformity of Social Studies Textbooks to the Critical Thinking Standards
}

\author{
Birsel Aybek ${ }^{1}$, Serkan Aslan ${ }^{2}$ \\ ${ }^{1}$ Assist.Prof. Dr., Cukurova University, Faculty of Education, Department of Educational Sciences, Adana, Turkey \\ ${ }^{2}$ Ministry of National Education, Nuri Ozaltin Primary School, Elazig, Turkey \\ Correspondence: Serkan Aslan, Ministry of National Education, Nuri Ozaltin Primary School, Elazig, Turkey.
}

Received: August 22, 2016

doi:10.11114/jets.v4i11.1830
Online Published: September 22, 2016

URL: http://dx.doi.org/10.11114/jets.v4i11.1830

\begin{abstract}
This present study aims to describe the classroom teachers' views towards the conformity of elementary school $4^{\text {th }}$ grade social studies textbooks to the critical thinking standards. A descriptive study, this research is a screening model. The sample of the study constitutes 122 classroom teachers. As a data collection tool; a scale was developed with a view to determining the compliance of elementary school $4^{\text {th }}$ grade social studies textbooks with critical thinking standards. Multivariate analysis of variance (MANOVA) along with descriptive statistics was used to analyze the data. Whether the conformity of elementary school $4^{\text {th }}$ grade social studies textbooks to the critical thinking standards differ by gender was examined, it was found that the difference was statistically significant in favor of male teachers; moreover, it does not show a significant difference in terms of gender and seniority, gender and participation in-service training regarding the examination of textbooks, gender and participation in course / seminar on critical thinking, gender and faculties they graduated.
\end{abstract}

Keywords: critical thinking, critical thinking standards, textbooks, prospective teachers

\section{Introduction}

Nowadays, one of the main goals of education is to provide students problem-solving, creative thinking and higher-order thinking skills such as critical thinking. Indeed, developed and developing countries have made some alterations for changing the curriculum with the aim of enabling students these skills. Our country has also made several amends in 2005 elementary school curriculum so as to keep pace with the era of education. New elementary school curriculum has been designed taking into account higher-order thinking skills. One of higher-order thinking skills, critical thinking is also among the required skills to enable the students within the context of curriculum implemented in the 2004-2005 academic year (Ministry of Education [MNE], 2005a; 2005b; 2009a; 2009b).

Various definitions have been made by different researchers about critical thinking. Paul and Elder (2007) defines critical thinking as an analyzing and evaluating art for the purpose of developing thinking while Celikkaya (2012) identifies critical thinking as a process by which high-level cognitive skills such as analysis, synthesis and evaluation are supposed to be used while assessing truth or mistake of a situation.

As can be understood from the above definitions, critical thinking is a way of thinking which provides an opportunity for using all aspects of life effectively (Kokdemir, 2003). Individuals having critical thinking skills are expected to access the solution easier through versatile thinking and to support their suggestions and claims with proof. Therefore, critical thinking skills should be ensured for students at all educational levels from elementary school to university (Sahinel, 2007). However, certain standards are required for the acquisition of these skills.

Nosich (2012) have argued that thinking is to meet high standards; therefore, he has revealed standards related to critical thinking one of higher-order thinking skills. Nosich (2012) refers that people exclude non-critical thoughts thanks to standards, which means that critical thinking standards serve as a filter. Besides, Nosich (2012) acknowledges that critical thinking standards are prerequisites of logical thinking. Thus, so that we can determine whether an idea is reasonable, we need to review it considering the critical thinking standards. Nosich (2012) has revealed that these standards are composed of clarity, accuracy, significance / relevance, completeness, depth / breadth and precision.

First, in terms of clarity, it is essential that thought be expressed clearly and easily understood; moreover, it should not 
be misunderstood, be expressed in detail simple and understandable (Nosich, 2012). Considering the standard of accuracy, thought is required to be correct, logical and the knowledge should be reliable; in addition it should be transferred in a correct sequence and reflects the truth as well as based upon reliable sources. When it comes to significance / relevance, important details of thoughts should be emphasized while transferring them, be focused on the important points, have a link between the topics discussed and highlight the main points etc. (Nosich, 2012). As to completeness standard, it is emphasized that thought should be transferred in a comprehensive manner and also topics should be explained in detail with various examples, enough time and evidence. Depth / width standard; the reasons should be disclosed comprehensively, in-depth information should be mentioned regarding the topic and it should be viewed from different perspectives. As for precision standard; topics should be transferred in a flawless manner, it must be certainty in mind, the topics should be detailed enough to express the causes of events (Nosich, 2012).

According to Ozdemir (2006), critical thinking helps to develop new solutions and also it questions whether proofs are sufficient or not. As to Beyer (1988), individuals having critical thinking skills can explicitly express problems and they do not act without thinking; furthermore, those having critical thinking skills control their work and they are willing to create new ideas as well as investigating and presenting the reasons of claims; finally, they have a tendency for consistently doubting until finding enough evidence. These skills are the main aim of Social Studies which is the most important lesson that especially prepares individuals for life. Thereby, acquiring students critical thinking skills in social studies is of great importance. It is required that textbooks be prepared depending upon the development these skills and the conformity of critical thinking standards in order to have students acquire critical thinking skills.

In our country, various studies have been carried out related to textbooks (Gecit \& Ozen, 2011; Karadas, Yasar \& Kirbaslar, 2012; Kosker \& Akoz, 2011). In the study conducted by Aybek and Aslan (2014), the conformity of the activities available in two units in elementary school $4^{\text {th }}$ grade social studies textbook for critical thinking standards was examined via document analysis. The results of the standard of clarity in critical thinking activities of these two units in the textbook accuracy, importance / relevance, high qualification standards, depth / width and is partially determined to meet the standards of accuracy. In this study, classroom teachers' views towards the conformity of elementary school $4^{\text {th }}$ grade social studies textbooks to the critical thinking standards were examined. In the study, more detailed results have been achieved by examining whether classroom teachers' views towards the conformity of elementary school $4^{\text {th }}$ grade social studies textbooks to the critical thinking standards differ depending upon gender, seniority, textbook examination and participation in-service training, participation in course / seminar related to critical thinking and faculties they have graduated. In addition, in the literature review, it has not been found such a study in which teachers' views of critical thinking standards in line with the activities in social studies textbooks were examined. Hence, it was decided to conduct such a study. With this study, it was thought to withdrawal the authors' attention in the preparation of textbooks considering critical thinking standards and thus increasing the quality of textbooks.

\subsection{Purpose}

This present study aims to determine the classroom teachers' views towards the conformity of elementary school $4^{\text {th }}$ grade social studies textbooks to the critical thinking standards. The following questions were sought related to this general aims.

1. What are the participation levels of teachers regarding the conformity of elementary $4^{\text {th }}$ grade social studies textbooks to the critical thinking standards?

2. Is there a significant difference between participation levels of teachers on the conformity of elementary $4^{\text {th }}$ grade social studies textbooks to the critical thinking standards and gender?

3. Is there a significant difference between participation levels of teachers on the conformity of elementary $4^{\text {th }}$ grade social studies textbooks to the critical thinking standards, gender and seniority?

4. Is there a significant difference between participation levels of teachers related to the conformity of elementary $4^{\text {th }}$ grade social studies textbooks to the critical thinking standards, gender and their participation in-service training based upon the examination of textbooks?

5. Is there a significant difference between participation levels of teachers related to the conformity of elementary $4^{\text {th }}$ grade social studies textbooks to the critical thinking standards, gender and their participation in course/ seminar on critical thinking?

6. Is there a significant difference between participation levels of teachers related to the conformity of elementary $4^{\text {th }}$ grade social studies textbooks to the critical thinking standards, gender and faculty they have graduated? 


\section{Methodology instead of Method}

\subsection{Research Model}

The research is a descriptive study in which screening model was used. Karasar (2012) stated that screening model is a research method which aims to describe a situation happening in the past or still existing as it is. In the present study, teachers' views towards the conformity of elementary $4^{\text {th }}$ grade social studies textbooks to the critical thinking standards have been depicted as they exist.

\subsection{Population and Sampling}

The population of the research constitutes classroom teachers teaching the fourth graders in 158 primary schools in Elazig in the 2014-2015 academic years. Primary schools in the villages located in the center are among 158 primary schools; however, they were not included in the sampling. Therefore, the sample of the research is composed of classroom teachers teaching the fourth graders in primary schools considering the accessibility. A scale was developed for 131 teachers working in these schools. 9 of them were not taken into consideration because of incorrect or incomplete markings. Finally, measurement instruments applied to 122 teachers were used. Teachers' personal characteristics were presented in Table 1.

Table 1. Distribution by personal characteristics of teachers

\begin{tabular}{|c|c|c|c|c|c|}
\hline Gender & $f$ & $\%$ & Faculty & $f$ & $\%$ \\
\hline Female & 63 & 52 & Faculty of Education & 87 & 71 \\
\hline Male & 59 & 48 & $\begin{array}{l}\text { Faculty of Science and } \\
\text { Literature }\end{array}$ & 15 & 12 \\
\hline \multicolumn{3}{|c|}{ Course/Seminar Regarding Critical Thinking } & $\begin{array}{ll}\text { Administrative } & \text { and } \\
\text { Economic Sciences } & \end{array}$ & 3 & 3 \\
\hline Participate & 23 & 19 & Other & 17 & 14 \\
\hline Do not Participate & 99 & 81 & Seniority & & \\
\hline $\begin{array}{l}\text { In-service training on the } \\
\text { textbooks }\end{array}$ & exar & of & $0-5$ years & 10 & 8 \\
\hline Participate & 17 & 14 & $6-10$ years & 47 & 39 \\
\hline \multirow[t]{2}{*}{ Do not Participate } & 105 & 86 & $11-15$ years & 21 & 17 \\
\hline & & & 16 years and over & 44 & 36 \\
\hline Total & 122 & 100 & Total & 122 & 100 \\
\hline
\end{tabular}

Analyzing Table 1, it was found that female teachers (52\%) are more than male teachers (48\%), seniority is between 6-10 years (39\%), they do not participate in-service training regarding the examination of textbooks $(86 \%), 81 \%$ of them do not participate in course / seminar related to critical thinking and $71 \%$ of them have been graduated from Faculty of Education.

\subsection{Data Collection Tools}

As a data collection tool; a scale was developed in order to determine the conformity of elementary $4^{\text {th }}$ grade social studies textbooks to the standards of critical thinking. During the preparation process of the scale, items were formed by examining critical thinking standards firstly developed by Nosich (2012). Thus, 49 items were determined.

Five classroom teachers serving at elementary school in fourth grade, getting a master's degree in different universities and academic members at Cukurova University, Department of Educational Sciences, Education Curriculum and Instruction teaching undergraduate and graduate courses related to critical thinking and serving as a thesis supervisor have presented their views about the items so as to ensure content validity of data collection tool. 42 of 49 items were determined to be used in accordance with the opinions of teachers and specialists. After the necessary adjustments and changes made in accordance with the opinions of teachers and specialists, the scale consisting of 42 items was applied to 122 teachers and exploratory factor analysis was conducted. Ho (2006), stated that the number of the sample would be 100 and over in exploratory factor analysis. As a result of the analysis results, Kaiser-Meyer-Olkin (KMO) value of the scale is .889 while the Bartlett test was found to be 2905,855 . Accordingly, the result of Bartlett test was statistically significant at the level of .05 ( $\mathrm{p}=.00$ ). According to Secer (2013), for the conformity of data for factor analysis, KMO coefficient is required to be higher than .80 and Bartlett test data must be significant. According to this reference, data are suitable for factor analysis. As a result of the exploratory factor analysis, when item factor loads were examined, factor loads of two items have been found to be below .30. These items were removed from the scale and were re-analyzed. As a result of the study, factor loads of 40 -items were determined to be above .30 . When the results of the factor analysis done for scale were examined, it was found that 40 items were divided into six factors whose core values are greater than 1. The variance explained by factors related to the scale was 58 306\%. Green, Salkind and Akey (2000) stated that breaking point chart is a significant data source for determining the dimensions of the scale. Breaking point chart was also examined by the researchers and hence it was recommended that the scale be composed of six dimensions. 
To measure the reliability of the scale, Cronbach Alpha coefficient was determined; therefore, openness factor of.93, accuracy factor of .94 , importance-relevance factor of .93 , completeness factor .93 , depth factor .93 and precision factor .93 were found. Cronbach's alpha coefficient for all items of the scale was .92 . These results indicate that the scale is highly reliable (Ozdamar, 2013). After all these processes, the scale is rated on 5-point Likert-type form as follows: Strongly Agree (5) Agree (4), Partially Agree (3) Disagree (2) Strongly Disagree (1).

\subsection{Data Analysis}

The research data were analyzed by means of using the statistical software package. At first, whether data meet general requirements of parametric tests was checked. Kolomogrov Smirnov test was performed with the aim of determining if data show normal distribution. Thus, it was observed that data showed normal distribution. During the analysis process, descriptive statistics and multivariate analysis of variance (MANOVA) were used in the study. Within the context of the research, whether multivariate normality assumptions were met or not was examined using Mahalanobis distance values. In the study, there are 6 dependent variables depending on the critical thinking standards. According to Pearson and Hartley (1958), in the study including 6 continuous variables, the critical value for Mahalanobis distance is 22.46. Mahalanobis values above this value are regarded as an extreme value (Pallant, 2005). In the study, Mahalanobis values were examined and no extreme values were found. One of the assumptions that must be met for MANOVA is the lack of multi-linear link between dependent variables. Dependent variables should be theoretically interrelated for the implementation of MANOVA (Field, 2009; Leech, Barrett \& Morgan, 2005). Besides, a very high correlation between the dependent variables (correlation coefficients above .80 or .90) (Pallant, 2005) has also caused several problems about MANOVA (Akbulut, 2011). In this research, it was found that there is a medium and low relationship between critical thinking standards. For the implementation of MANOVA, another assumption is the homogeneity of variance-covariance matrix, which is determined by means of "Box's M" test. That Box's $M$ test is statistically insignificant means homogeneity of variance-covariance matrices is met; however, when Box's $M$ test is statistically significant, this assumption is violated. Since Box's M test is significantly affected by the number of participants in the study and Box's $M$ test is found much easier significant in the studies the number of participants are higher (Tabachnick \& Fidell, 2007), significant measure for this test was recommended as.025, .01 (Mettler \& the Vannat, 2010) or. 001 (Pallant, 2005). In the study, significance criterion for Box's M test was taken as .001. To determine the level of the items in the scale, score ranges are considered as follows: Strongly disagree $1.00-1.80$, Disagree $1.81-2.60$, Partially Agree $2.61-3.40$, Agree $3.41-4.20, \quad$ Strongly agree $4.21-5.00$.

\section{Results}

In this section, findings have been presented related to the participation levels of the classroom teachers' views towards the conformity of elementary school $4^{\text {th }}$ grade social studies textbooks to the critical thinking standards, their views differ depending on gender, seniority, their participation in-service training on the examination of textbooks and course/seminar regarding critical thinking as well as faculties they graduated.

Participation levels of the teachers regarding the compliance of elementary school fourth grade social studies textbooks with the standards of critical thinking are presented in Table 2.

Table 2. Participation levels of the teachers regarding the compliance of elementary school fourth grade social studies textbooks with the standards of critical thinking

\begin{tabular}{llllll}
\hline Standards & $\mathrm{n}$ & $\overline{\mathrm{X}}$ & Ss & Max & Min \\
\hline Clarity & 122 & 2,97 &, 776 & 5,00 & 1,00 \\
Accuracy & 122 & 3,49 &, 690 & 5,00 & 1,40 \\
Significance/ & 122 & 3,15 &, 621 & 5,00 & 1,38 \\
Relevance & 122 & 2,72 &, 848 & 5,00 & 1,00 \\
Completeness & 122 & 2,83 &, 732 & 5,00 & 1,17 \\
Depth/Breadth & 122 & 3,08 &, 577 & 4,43 & 1,71 \\
Precision & 122 & 3,03 &, 599 & 4,90 & 1,45 \\
General &
\end{tabular}

When Table 2 is examined, it was found that teachers expressed their opinions about the critical thinking standards of elementary school fourth grade social studies textbook as follows: clarity $(\overline{\mathrm{X}}=2,97)$, significance-relevance $(\overline{\mathrm{X}}=3,15)$, completeness $(\overline{\mathrm{X}}=2,72)$, depth-breadth $(\overline{\mathrm{X}}=2,83)$, precision $(\overline{\mathrm{X}}=3,08)$ and general $(\overline{\mathrm{X}}=3,03)$ as "partially agree" while accuracy $(\overline{\mathrm{X}}=3,49)$ as "agree".

One factor MANOVA results related to the participation levels of teachers on the conformity of elementary $4^{\text {th }}$ grade social studies textbooks to the critical thinking standards and gender were presented in Table 3. 
Table 3. One factor MANOVA results related to the conformity of elementary $4^{\text {th }}$ grade social studies textbooks to the critical thinking standards depending on gender

\begin{tabular}{|c|c|c|c|c|c|c|c|c|}
\hline $\begin{array}{l}\text { Dependent } \\
\text { Variable }\end{array}$ & Gender & $\mathrm{n}$ & $\bar{X}$ & ss & $\mathrm{sd}$ & $\mathrm{F}$ & $\mathrm{p}$ & $\eta^{2}$ \\
\hline \multirow{2}{*}{ Clarity } & $\mathrm{F}$ & 63 & 2,84 & ,701 & \multirow{2}{*}{1} & \multirow{2}{*}{3,78} & \multirow{2}{*}{, 54} & \multirow{2}{*}{,031 } \\
\hline & M & 59 & 3,11 & 832 & & & & \\
\hline \multirow{2}{*}{ Accuracy } & $\mathrm{F}$ & 63 & 3,41 & 664 & \multirow{2}{*}{1} & \multirow{2}{*}{1,66} & \multirow{2}{*}{,20 } & \multirow{2}{*}{,014 } \\
\hline & M & 59 & 3,57 &, 713 & & & & \\
\hline Significance & $\mathrm{F}$ & 63 & 3,10 &, 569 & \multirow{2}{*}{1} & \multirow{2}{*}{, 82} & \multirow{2}{*}{,36 } & \multirow{2}{*}{, 007} \\
\hline Relevance & M & 59 & 3,20 & 673 & & & & \\
\hline \multirow{2}{*}{ Completeness } & $\mathrm{F}$ & 63 & 2,51 & 798 & \multirow{2}{*}{1} & \multirow{2}{*}{8,50} & \multirow{2}{*}{,00 } & \multirow{2}{*}{,066 } \\
\hline & M & 59 & 2,95 & 847 & & & & \\
\hline \multirow{2}{*}{ Depth-Breadth } & $\mathrm{F}$ & 63 & 2,70 & 680 & \multirow{2}{*}{1} & \multirow{2}{*}{4,55} & \multirow{2}{*}{,03 } & \multirow{2}{*}{,037 } \\
\hline & M & 59 & 2,98 & ,763 & & & & \\
\hline \multirow{2}{*}{ Precision } & $\mathrm{F}$ & 63 & 2,97 & ,568 & \multirow{2}{*}{1} & \multirow{2}{*}{4,70} & \multirow{2}{*}{,03 } & \multirow{2}{*}{, 038} \\
\hline & M & 59 & 3,19 & ,569 & & & & \\
\hline
\end{tabular}

With the aim of determining whether the conformity of elementary $4^{\text {th }}$ grade social studies textbooks to the critical thinking standards differ significantly depending on gender, multivariate variance analysis (single factor MANOVA) was performed. Wilks 'Lambda Test results have revealed that linear combinations of the conformity of teachers' critical thinking standards in terms of gender show a significant difference (Wilk's $\Lambda=.898, \mathrm{~F}_{1,120}=2,173, \mathrm{p}=.04$ ). The results of one-factor ANOVA test done for the conformity of elementary school $4^{\text {th }}$ grade social studies textbooks to the critical thinking standards were presented in Table 3. As shown in Table 3, it was revealed that completeness $\left(\mathrm{F}_{1-120}=8,50\right.$, $\mathrm{p} \leq .05)$, depth-breadth $\left(\mathrm{F}_{1-120}=4,55, \mathrm{p} \leq .05\right)$ and precision levels $\left(\mathrm{F}_{1-120}=4,70, \mathrm{p} \leq .05\right)$ differ significantly depending upon gender; whereas, clarity, accuracy and significance-relevance levels do not show significant difference depending upon gender. In addition, it can be said that the relationship between critical thinking standards such as clarity, accuracy, significance-relevance, depth-breadth and precision and gender is low while the interaction between gender and completeness is effective at the medium level (Green \& Salkind, 2013).

Descriptive statistical results related to the participation levels of teachers on the conformity of elementary $4^{\text {th }}$ grade social studies textbooks to the critical thinking standards, gender and seniority are presented in Table 4.

Table 4. Standard mean and standard deviation values of critical thinking standards regarding gender depending on seniority

\begin{tabular}{|c|c|c|c|c|c|c|c|c|c|c|c|c|c|c|}
\hline \multirow[t]{2}{*}{ Seniority } & \multirow{2}{*}{ Gender } & \multirow{2}{*}{$\mathrm{n}$} & \multicolumn{2}{|c|}{ Clarity } & \multicolumn{2}{|c|}{ Accuracy } & \multicolumn{2}{|c|}{$\begin{array}{l}\text { Significance } \\
\text { Relevance }\end{array}$} & \multicolumn{2}{|c|}{ Completeness } & \multicolumn{2}{|c|}{ Depth/Breadth } & \multicolumn{2}{|c|}{ Precision } \\
\hline & & & $\overline{\mathrm{X}}$ & SS & $\overline{\mathrm{X}}$ & SS & $\bar{X}$ & Ss & $\bar{X}$ & SS & $\overline{\mathrm{X}}$ & SS & $\overline{\mathrm{X}}$ & SS \\
\hline \multirow{2}{*}{$0-5$ years } & Male & 9 & 3,04 & ,866 & 3,64 & ,622 & 3,18 & ,586 & 2,41 & ,957 & 2,50 & ,853 & 2,70 & ,634 \\
\hline & Female & 1 & 2,71 & 823 & 4,00 & 597 & 4,00 & 610 & 4,00 & 1,047 & 4,00 &, 934 & 2,98 & 676 \\
\hline \multirow{2}{*}{ 6-10 years } & Male & 25 & 2,81 & ,708 & 3,50 & ,566 & 3,07 & ,494 & 2,38 & ,701 & 2,77 & ,577 & 3,00 & ,485 \\
\hline & Female & 22 & 3,26 & ,769 & 3,50 & 675 & 3,15 & ,594 & 2,97 & 899 & 2,96 &, 886 & 4,00 & 620 \\
\hline $11-15$ & Male & 7 & 2,95 & ,587 & 3,40 & ,400 & 3,11 & ,572 & 2,61 & ,593 & 2,73 & ,843 & 3,05 & ,329 \\
\hline years & Female & 14 & 3,04 &, 725 & 3,54 & 609 & 3,25 & ,578 & 2,88 & 629 & 2,91 &, 576 & 3,24 & ,440 \\
\hline 16 years & Male & 22 & 2,76 & 680 & 3,23 & ,822 & 3,11 & 671 & 2,68 & ,893 & 2,68 & 694 & 3,00 & 692 \\
\hline and over & Female & 22 & 3,03 & ,977 & 3,66 & ,833 & 3,25 & 810 & 2,92 & ,934 & 2,99 &, 751 & 3,21 & ,590 \\
\hline
\end{tabular}

Two factor MANOVA was conducted to determine the common effect of gender and seniority on the participation levels of teachers on the conformity of elementary $4^{\text {th }}$ grade social studies textbooks to the critical thinking standards. When MANOVA assumptions were checked, according to Box's $M$ statistics, dispersion matrix has been found to ensure homogeneity assumptions $\left(\mathrm{F}_{126-1,471}=237,296, \mathrm{p}=, 001\right)$. Wilks 'Lambda Test results have indicated that linear combinations of the conformity of teachers' critical thinking standards for elementary school $4^{\text {th }}$ grade social studies textbooks in terms of gender and seniority do not differ significantly (Wilk's $\Lambda=.898, \mathrm{~F}_{1,120}=2,173, \mathrm{p}=.04$ ). Accordingly, it has been found out that gender and seniority are not factors affecting the conformity of teachers' critical thinking standards for elementary school $4^{\text {th }}$ grade social studies textbooks significantly. In addition, it has been observed that the interaction of gender and seniority with the dimensions of critical thinking standards is effective at a low level.

Descriptive statistical results related to the participation levels of teachers on the conformity of elementary $4^{\text {th }}$ grade social studies textbooks for the critical thinking standards, gender and participation or non-participation in-service training on the examination of textbooks are presented in Table 5. 
Table 5. Standard mean and standard deviation values of critical thinking standards regarding participation or non-participation in-service training on the examination of textbooks depending on gender

\begin{tabular}{|c|c|c|c|c|c|c|c|c|c|c|c|c|c|c|}
\hline \multirow{2}{*}{$\begin{array}{l}\text { In-service } \\
\text { Training }\end{array}$} & \multirow{2}{*}{ Gender } & \multirow{2}{*}{$\mathrm{n}$} & \multicolumn{2}{|c|}{ Clarity } & \multicolumn{2}{|c|}{ Accuracy } & \multicolumn{2}{|c|}{$\begin{array}{l}\text { Significance } \\
\text { Relevance }\end{array}$} & \multicolumn{2}{|c|}{ Completeness } & \multicolumn{2}{|c|}{ Depth/Breadth } & \multicolumn{2}{|c|}{ Precision } \\
\hline & & & $\bar{X}$ & SS & $\bar{X}$ & SS & $\bar{X}$ & Ss & $\bar{X}$ & SS & $\bar{X}$ & SS & $\bar{X}$ & SS \\
\hline \multirow{2}{*}{ I participate } & Female & 8 & 2,83 & ,68 & 3,27 & ,97 & 3,06 & ,43 & 2,37 & 50 & 2,77 &, 53 & 2,92 &, 55 \\
\hline & Male & 9 & 2,68 & ,95 & 3,37 &, 86 & 2,72 & ,99 & 2,71 & ,92 & 2,48 &, 87 & 2,82 &, 56 \\
\hline I don't & Female & 55 & 2,84 &, 70 & 3,44 & ,61 & 3,44 &, 58 & 2,54 &, 83 & 2,69 &, 70 & 2,98 &, 57 \\
\hline participate & Male & 50 & 3,19 &, 79 & 3,61 & ,68 & 3,29 &, 57 & 2,75 &, 83 & 3,07 & ,71 & 3,26 &, 54 \\
\hline
\end{tabular}

Two factor MANOVA was conducted to determine the common effect of gender and participation or non-participation in-service training regarding the examination of textbooks upon the participation levels of teachers on the conformity of elementary $4^{\text {th }}$ grade social studies textbooks for the critical thinking standards. When MANOVA assumptions were checked, according to Box's M statistics, dispersion matrix has been found to ensure homogeneity assumptions $\left(\mathrm{F}_{63-1,224}=102,391, \mathrm{p}=.114\right)$. Wilks 'Lambda Test results have showed that linear combinations of the conformity of teachers' critical thinking standards for elementary school $4^{\text {th }}$ grade social studies textbooks in terms of gender and participation or non-participation in-service training regarding the examination of textbooks do not differ significantly (Wilk's $\Lambda=.918, \mathrm{~F}_{1,118}=1,687, \mathrm{p}=.131$ ). Hence, gender and participation or non-participation in-service training regarding the examination of textbooks are said to be not the factors affecting teachers' participation levels of the conformity of critical thinking standards for elementary school $4^{\text {th }}$ grade social studies textbooks significantly. Besides, it has been observed that the interaction of gender and participation or non-participation in-service training with the dimensions of critical thinking standards is effective at a low level.

Descriptive statistical results related to the participation levels of teachers on the conformity of elementary $4^{\text {th }}$ grade social studies textbooks for the critical thinking standards, gender and participation or non-participation in course/seminar regarding critical thinking are presented in Table 6.

Table 6. Standard mean and standard deviation values of critical thinking standards about participation or non-participation in course/seminar regarding critical thinking depending on gender

\begin{tabular}{|c|c|c|c|c|c|c|c|c|c|c|c|c|c|c|}
\hline \multirow{2}{*}{$\begin{array}{l}\text { Course/Seminar } \\
\text { Regarding } \\
\text { Critical Thinking }\end{array}$} & \multirow[t]{2}{*}{ Gender } & \multirow[t]{2}{*}{$\mathrm{n}$} & \multicolumn{2}{|c|}{ Clarity } & \multicolumn{2}{|c|}{ Accuracy } & \multicolumn{2}{|c|}{$\begin{array}{l}\text { Significance } \\
\text { Relevance }\end{array}$} & \multicolumn{2}{|c|}{ Completeness } & \multicolumn{2}{|c|}{ Depth/Breadth } & \multicolumn{2}{|c|}{ Precision } \\
\hline & & & $\bar{X}$ & SS & $X$ & SS & $\bar{X}$ & SS & $\bar{X}$ & SS & $\bar{X}$ & SS & $\bar{X}$ & SS \\
\hline \multirow{2}{*}{ I participate } & Female & 12 & 2,66 & 62 & 3,13 & 67 & 3,04 & ,40 & 2,48 & ,64 & 2,68 & 45 & 2,82 & ,42 \\
\hline & Male & 11 & 3,06 & ,71 & 3,69 & ,49 & 3,27 & ,79 & 2,87 & 67 & 2,87 & ,78 & 3,37 & 44 \\
\hline don't & Female & 51 & 2,89 & ,71 & 3,48 & 65 & 3,11 & 60 & 2,52 &, 83 & 2,70 &, 72 & 3,01 &, 59 \\
\hline participate & Male & 48 & 3,13 & ,86 & 3,55 &, 75 & 3,19 & 65 & 2,97 &, 88 & 3,00 & ,76 & 3,15 & ,59 \\
\hline
\end{tabular}

Table 7. Standard mean and standard deviation values of critical thinking standards regarding faculties they graduated depending on gender

\begin{tabular}{|c|c|c|c|c|c|c|c|c|c|c|c|c|c|c|c|}
\hline \multirow{2}{*}{$\begin{array}{l}\text { Faculty } \\
\text { Graduated }\end{array}$} & \multirow[t]{2}{*}{ They } & \multirow[t]{2}{*}{ Gender } & \multirow[t]{2}{*}{$\mathrm{n}$} & \multicolumn{2}{|c|}{ Clarity } & \multicolumn{2}{|c|}{ Accuracy } & \multicolumn{2}{|c|}{$\begin{array}{l}\text { Significance } \\
\text { Relevance }\end{array}$} & \multicolumn{2}{|c|}{ Completeness } & \multicolumn{2}{|c|}{ Depth/Breadth } & \multicolumn{2}{|c|}{ Precision } \\
\hline & & & & $\mathrm{X}$ & SS & $X$ & SS & $\bar{X}$ & Ss & $\bar{X}$ & SS & $\mathrm{X}$ & SS & $\bar{X}$ & SS \\
\hline \multirow{2}{*}{ Education } & \multirow[b]{3}{*}{ and } & Female & 42 & 2,86 & ,72 & 3,48 & ,57 & 3,11 & ,52 & 2,46 & ,72 & 2,72 & ,65 & 2,97 & ,54 \\
\hline & & Male & 45 & 3,03 &, 78 & 3,48 & ,68 & 3,15 & 62 & 2,82 &, 81 & 2,94 &, 73 & 3,13 &, 59 \\
\hline \multirow{2}{*}{$\begin{array}{l}\text { Science } \\
\text { Letters }\end{array}$} & & Female & 7 & 2,81 & 63 & 3,54 & ,61 & 3,12 & ,83 & 2,71 & 1,15 & 2,95 &, 84 & 3,20 & ,66 \\
\hline & & Male & 8 & 3,28 & ,88 & 3,50 &, 85 & 3,51 & 60 & 3,62 &, 58 & 3,37 &, 72 & 3,41 & ,27 \\
\hline \multirow{2}{*}{\multicolumn{2}{|c|}{$\begin{array}{l}\text { Administrative } \\
\text { and Economic } \\
\text { Sciences }\end{array}$}} & Female & 2 & 3,21 &, 70 & 3,10 &, 14 & 3,56 &, 79 & 3,07 & ,90 & 2,91 &, 58 & 3,35 &, 30 \\
\hline & & Male & 1 & 3,00 & ,61 & 2,80 & ,09 & 2,62 & ,63 & 2,42 &, 78 & 2,50 & ,69 & 2,28 & ,52 \\
\hline \multirow{2}{*}{\multicolumn{2}{|c|}{ Others }} & Female & 12 & 2,76 & ,71 & 3,10 & ,95 & 2,98 &, 55 & 2,50 &, 87 & 2,43 & ,68 & 2,76 & ,57 \\
\hline & & Male & 17 & 3,01 & 1,21 & 3,96 & ,43 & 3,25 & 1,18 & 3,17 & 1,14 & 2,80 & ,76 & 3,60 & ,27 \\
\hline
\end{tabular}

Two factor MANOVA was performed in order to determine the common effect of gender and participation or non-participation in course/seminar regarding critical thinking upon the participation levels of teachers on the conformity of elementary $4^{\text {th }}$ grade social studies textbooks for the critical thinking standards. When MANOVA assumptions were checked, according to Box's M statistics, dispersion matrix has been found to ensure homogeneity assumptions $\left(\mathrm{F}_{63-1,312}=100,195, \mathrm{p}=.051\right)$. Wilks 'Lambda Test results have revealed that linear combinations of the conformity of teachers' critical thinking standards for elementary school $4^{\text {th }}$ grade social studies textbooks in terms of gender and participation or non-participation in course/seminar regarding critical thinking do not differ significantly (Wilk's $\Lambda=.941, \mathrm{~F}_{1,118}=1,191, \mathrm{p}=.316$ ). Thus, it can be expressed that gender and participation or non-participation in course/seminar regarding critical thinking are not the effective factors on teachers' participation levels of the conformity of critical thinking standards for elementary school $4^{\text {th }}$ grade social studies textbooks significantly. Moreover, it has been observed that the interaction of gender and participation or non-participation in course/seminar regarding critical 
thinking with the dimensions of critical thinking standards is effective at a low level.

Descriptive statistical results concerning the participation levels of teachers on the conformity of elementary $4^{\text {th }}$ grade social studies textbooks for the critical thinking standards, gender and faculties they graduated are presented in Table 7.

Two factor MANOVA was performed with the aim of determining the common effect of gender and faculties they graduated upon the participation levels of teachers on the conformity of elementary $4^{\text {th }}$ grade social studies textbooks for the critical thinking standards. When MANOVA assumptions were checked, according to Box's M statistics, dispersion matrix has been found to ensure homogeneity assumptions $\left(\mathrm{F}_{84-1,466}=169,416, \mathrm{p}=, 004\right)$. Wilks 'Lambda Test results have revealed that linear combinations of the conformity of teachers' critical thinking standards for elementary school $4^{\text {th }}$ grade social studies textbooks in terms of gender and faculties they graduated do not differ significantly (Wilk's $\Lambda=.941, \mathrm{~F}_{1,118}=1,191, \mathrm{p}=.316$ ). Accordingly, it can be expressed that gender and faculties they graduated are not the effective factors on teachers' participation levels of the conformity of critical thinking standards for elementary school $4^{\text {th }}$ grade social studies textbooks significantly. Moreover, it has been observed that the interaction of gender and faculties they graduated with the dimensions of critical thinking standards is effective at a low level.

\section{Discussion and Conclusion}

In the study, it was found that teachers expressed their opinions about the critical thinking standards of elementary school fourth grade social studies textbook as follows: clarity, significance-relevance, completeness, depth-breadth, precision and general as "partially agree" while accuracy as "agree". It can be interpreted that this was prepared as partly appropriate for the critical thinking standards of elementary school fourth year social studies textbook. In the study conducted by Demir, Tutkun, Sahin and Genc (2014) related to teachers' views on the conformity of the activities in elementary school $4^{\text {th }}$ grade social studies workbooks for critical thinking, it was found that the activities in the workbooks is appropriate for critical thinking at a medium level. These results also support our research. In the study conducted by Buyukaslan (2011), it was obtained that the activities existing in the $4^{\text {th }}$ and $5^{\text {th }}$ grade Turkish textbooks are appropriate for critical thinking skills at a high level. On the other, Aybek and Aslan (2014) conducted a study in which two units in elementary school fourth grade social science textbook were determined to meet clarity, accuracy, significance / relevance, completeness standards at a high rate while they partially meet depth / breadth and precision standards. The reason for this difference is that this study embodies two units and the textbook from different publisher has been examined. Under the strength of research results, that classroom teachers evaluate social studies textbook in accordance with the standards of critical thinking at a medium and high level is regarded as the most important result. This will contribute to the realization of the objectives of developing higher level thinking skills one of the main objectives of the present study. In this regard, one of the most significant tools used in the learning environment textbooks must be prepared based upon this thinking skill (Aybek \& Aslan, 2014; Ozturk \& Razgatlioglu, 2013).

In the study, whether the conformity of elementary $4^{\text {th }}$ grade social studies textbooks to the critical thinking standards differ depending on gender was examined, it was found that there is a significant difference in favor of male teachers, which reveals that male and female teachers' views on the conformity of elementary school fourth grade social studies textbooks for the standards of critical thinking differ significantly. Besides, in the study conducted by Demir, Tutkun, Sahin and Genc (2014), the conformity of questions in the elementary school fourth grade social studies textbooks for the standards of critical thinking varies depending on gender.

In the study, it was found that the conformity of elementary school $4^{\text {th }}$ grade social studies textbooks for the critical thinking standards does not differ depending upon gender, seniority, textbook examination and participation in-service training, participation in course / seminar regarding critical thinking and faculties they graduated. Based on these results, it can be mentioned that the conformity of elementary school $4^{\text {th }}$ grade social studies textbooks for the critical thinking standards depending upon gender, seniority, textbook examination and participation in-service training, participation in course / seminar regarding critical thinking and faculties they graduated does not significantly affect teachers' views.

\section{Recommendations}

Such recommendations have been presented as a result of the study:

1. As a result of the study, teachers expressed their opinions as partially agree related to the conformity of elementary school $4^{\text {th }}$ grade social studies textbooks for the critical thinking standards. This shows that elementary $4^{\text {th }}$ grade social studies textbook is partially appropriate for critical thinking standards. During preparation process of textbooks, it will be useful for publishers to collaborate with experts conducting studies on critical thinking and program development specialists In this way, preparing textbooks appropriate for the standards of critical thinking will be provided.

2. Various studies can be done examining the conformity of different textbooks for critical thinking standards. Thus, whether textbooks are prepared depending on developing critical thinking skills may be determined. 
3. Various studies are supposed to be done to analyze the conformity of textbooks for critical thinking standards using different research methods

4. Various studies can be performed to determine the conformity of textbooks for critical thinking standards through asking other stakeholders' views.

\section{References}

Akbulut, Y. (2011). Sosyal bilimlerde SPSS uygulamaları. İstanbul: İdeal Yayınları.

Aybek, B., \& Aslan, S. (2014). Ilkokul dördüncü sınıf sosyal bilgiler ders kitabında yer alan "geçmişimi öğreniyorum ve yaşadı̆̆ımı yer” "̈̈nitelerinin eleştirel düşünme standartları doğrultusunda incelenmesi. $1^{\text {st }}$ International Eurasian Educational Research Congress. (24-26/April/2014), İstanbul: İstanbul University.

Beyer, K. B. (1988). Developing as cope and sequence for thinking skills instruction. Educational Leadership, 45(7) 26-30.

Büyükarslan, Z. (2011). İlköğretim dördüncü ve beşinci sınıf Türkçe ders kitaplarında yer alan metin etkinliklerinin eleştirel düşünme becerileriyle örtüşme düzeyi. Yayımlanmamış yüksek lisans tezi. Atatürk Üniversitesi, Erzurum.

Çelikkaya, T. (2012). Sosyal bilgiler dersinde öğrencilerin eleştirel düşünme becerilerini geliştirmek için öğretmenlerin yaptıkları etkinlikler. The Journal of Academic Social Scince Studies, 5(5), 57-74.

Demir, M. K., Tutkun, T., Şahin, Ç., \& Genç, S. Z. (2014). Sosyal bilgiler etkinliklerinin eleştirel düşünmeye uygunluğu. Uşak Üniversitesi Sosyal Bilimler Dergisi, 7(1), 217-229.

Demir, M. K., Tutkun, T., Şahin, Ç., \& Genç, S. Z. (2014). Sosyal bilgiler ders kitaplarındaki soruların eleştirel düşünmeye uygunluğu. Abant İzzet Baysal Üniversitesi Eğitim Fakültesi Dergisi, 14(1), 289-303.

Field, A. (2009). Discovering statics using SPSS. London: SAGE Publications Ltd.

Geçit, Y., \& Özen, İ. (2011). İlköğretim dördüncü sınıf sosyal bilgiler ders kitabının öğrenci görüşlerine göre değerlendirilmesi. 10. Ulusal Sınıf Öğretmenliği Sempozyumu. Sivas: Cumhuriyet Üniversitesi.

Green, S. B., \& Salkind, N. J. (2013). Using SPSS for windows and macintosh: Analyzing and understanding data. New Jersey: Pearson.

Green, S. B., Salkind, N. J., \& Akey, M. (2000). Using SPSS for windows: Analyzing and understanding data. New Jersey: Prentice Hall.

Ho, R. (2006). Handbook of Univariate and Multivariate Data Analysis and Interpretation with SPSS. London \& New York: Chapman \& Hall. http://dx.doi.org/10.1201/9781420011111

Karadaş, A., Yaşar, Z., \& Kırbaşlar, G. (2012). 4 ve 5. sınıf fen ve teknoloji kitaplarında “madde ve değişism” öğrenme alanı etkinliklerinin incelenmesi. Necatibey Eğitim Fakültesi Elektronik Fen ve Matematik Ĕ̈itimi Dergisi, 6(1), 94-123.

Karasar, N. (2012). Bilimsel araştırma yöntemi. Ankara: Nobel.

Kökdemir, D. (2003). Belirsizlik durumlarında karar verme ve problem çözme. Yayınlanmamış doktora tezi, Ankara Üniversitesi, Anakara.

Köşker, N., \& Aköz, Y. (2011). İlköğretim 4 ve 5. sınıf sosyal bilgiler ders kitapları ve öğrenci çalışma kitaplarındaki soruların incelenmesi. 10. Ulusal Sınıf Öğretmenliği Sempozyumu. Sivas: Cumhuriyet Üniversitesi.

Leech, N. L., Barlett, K. C., \& Morgan, G. A. (2005). SPSS for Intermediate Statistics; Use and Interpretation. Mahwah, NJ: Lawrence Erlbaum Associates.

MEB. (2005a). Ilköğretim fen ve teknoloji dersi (4 ve 5. sinıflar) ögretim programı. Ankara: Devlet Kitapları Basımevi.

MEB. (2005b). Illköğretim sosyal bilgiler 4 ve 5. sınıf programı. Ankara: Devlet Kitapları Basımevi.

MEB. (2009a). Ilkögretim 1, 2 ve 3. sınıflar hayat bilgisi dersi ögretim programı ve kılavuzu. Ankara: Devlet Kitapları Basimevi.

MEB. (2009b). Illköğretim Türkçe dersi öğretim programı ve kılavuzu (1-5. sınıflar). Ankara: Devlet Kitapları Basımevi.

Mertler, C. A., \& Vannata, R. A. (2010). Advanced and multivariate statistical methods: practical application and interpretation. Los Angeles: Pyrczak Publishing.

Nosich, G. M. (2012). Learning to think things through: A guide to critical thinking across the curriculum. New Jersey: Prentice-Hall.

Özdamar, K. (2013). Paket programlar ile istatistiksel veri analizi. Ankara: Nisan Kitapevi. 
Özdemir, D. (2006). Sosyal bilgiler dersinin düşünme becerilerini kazandırma düzeyine ilişsin öğretmen görüşleri. Yayınlanmamış yüksek lisans tezi, Anadolu Üniversitesi, Eskişehir.

Öztürk, E., \& Razgatlıŏlu, M. (2013). 5. sınıf Türkçe ders kitaplarının eleştirel düşünme açısından incelenmesi. International Journal of Human Sciences, 10 (1), 445-458.

Pallant, J. (2005). SPSS survival manual: a step by step gutde to data analysis using spss for windows. Australia: Australian Copyright.

Paul, R., \& Elder, L. (2007). The miniature guide to critical thinking: Conceptsand Tools. Foundation for Critical Thinking Press.

Pearson, E. S., \& Hartley, H. O. (1958). Biometrika tables for statistician. New York: Cambridge University Press.

Şahinel, S. (2007). Eleştirel düşünme Ö. Demirel (Edt.). Eğitimde yeni yönelimler. Ankara: Pegem A.

Seçer, İ. (2013). SPSS ve LISREL ile pratik veri analizi. Ankara: Anı.

Tabachnick, B. G., \& Fidell, L. S. (2007). Using multivariate statistics. Boston: Pearson Education, Inc.

This work is licensed under a Creative Commons Attribution 3.0 License. 